\title{
Health, environment and working conditions in tobacco cultivation: a review of the literature
}

\author{
Saúde, ambiente e condições de trabalho no cultivo de tabaco: \\ revisão de literatura
}

Deise Lisboa Riquinho ${ }^{1}$

Elida Azevedo Hennington ${ }^{1}$

${ }^{1}$ Escola Nacional de Saúde

Pública, Fundação Oswaldo

Cruz. Rua Leopoldo

Bulhões 1480/503,

Manguinhos. 21041-210

Rio de Janeiro RJ.

deiselis@terra.com.br

\begin{abstract}
This study presents a review of the literature published between 1979 and 2010 on health and working conditions in tobacco cultivation, with particular emphasis on the Brazilian context. A review of computerized databases (PubMed, Scopus, WilsonWeb and Bireme/PAHO Virtual Health Library - Public Health) was carried out using the following search terms: tobacco, agricultural worker health, agricultural worker disease, working conditions, unsafe working conditions, occupational risk, occupational disease, and labor force. Articles published in English, Spanish and Portuguese were analyzed. Thirty-seven articles were selected from 214 references that were initially identified. Thirty-four additional publications (reports, etc.) were also analyzed. Among the many effects described in the literature, especially noteworthy are "green tobacco sickness," respiratory disorders, musculoskeletal injuries, mental disorders, and a negative environmental impact. Very few studies have been carried out in Brazil.

Key words Tobacco, Occupational risk, Health of the rural population, Working conditions, Public health
\end{abstract}

Resumo Este estudo propõe uma revisão da literatura científica publicada entre 1979 e 2010, sobre condições de trabalho no cultivo do tabaco, como ênfase particular no contexto brasileiro. Foi realizada revisão de literatura com consulta às bases de dados Pubmed, Scopus, Wilson Web e BVS Saúde Pública (Bireme OPAS). Os descritores utilizados foram: tabaco, saúde do trabalhador rural, doença dos trabalhadores agrícolas, condições de trabalho, condições inseguras no trabalho, doenças do trabalho e força de trabalho. Foram selecionados artigos publicados em inglês, espanhol e português. Trinta e sete artigos foram selecionados a partir de 214 referências que foram inicialmente identificados. Trinta e quatro outras publicações (relatórios técnico, livros e outros) também foram analisadas. Entre os muitos efeitos descritos na literatura, destaca-se "doença da folha do tabaco verde", distúrbios respiratórios, lesões músculo-esqueléticas, doenças mentais, e um impacto negativo relacionado ao meio ambiente. No Brasil poucos estudos têm sido realizados sobre este tema.

Palavras-chave Tabaco, Riscos ocupacionais, Saúde da população rural, Condições de trabalho, Saúde pública 


\section{Introduction}

The phenomenon of shifting tobacco production from developed to developing countries such as Brazil has been favored by a decrease in government subsidies in developed regions, an increase in smoking control and, consequently, production costs, and a decrease in tobacco profits ${ }^{1}$. The United States of America has experienced the steepest decline, from $20 \%$ of world tobacco output to $8 \%$ between 1970 and 2000, followed by the European Union, whose production share fell from $14 \%$ to $7 \%$. A similar process has occurred in Japan, with production falling by half over the same period ${ }^{2}$. Despite this production shift, profits are still repatriated to industry headquarters in developed countries, as is the case of Philip Morris, headquartered in the U.S., and Souza Cruz, a subsidiary of British American Tobacco, whose profits are transferred to the United Kingdom ${ }^{3}$.

In addition to production, tobacco consumption is also highest in developing countries. Currently, the number of smokers in the world is estimated at 1.3 billion, of which $84 \%$ live in developing countries, a figure likely to reach $88 \%$ by the end of $2025^{4,5 .}$ It is well known that tobacco users are at higher risk of developing and dying prematurely of several types of cancer, heart disease and respiratory diseases, which may result in income deprivation and additional health care $\operatorname{costs}^{3-6}$.

Considering this scenario of progressive expansion of production and consumption of tobacco in developing countries, in 1999, more than 190 World Health Organization (WHO) member countries proposed, during the $52^{\text {nd }}$ session of the World Health Assembly, the adoption of the first International Public Health Treaty, the Framework Convention on Tobacco Control (FCTC). For about four years, WHO member states discussed tobacco-related issues until a consensus was reached. The consensus statement was unanimously endorsed during the $56^{\text {th }}$ session of the Assembly in May 2003. The WHO FCTC has 172 Signatories, which makes it one of the most widely embraced treaties in United $\mathrm{Na}$ tions history. The purpose of the FCTC is to make countries converge in adopting measures in response to the globalization of the tobacco epidemic, by creating international standards to control and regulate a variety of aspects, from advertisement and sponsorship, price and tax policies, illegal sales and passive smoking to policies supporting agricultural diversification, among others ${ }^{3,4,7}$.
The complex interplay between tobacco production and consumption translates into a major economic and public health challenge for Brazil and the world, with specific population groups such as rural workers and communities being more vulnerable. The aim of the present study was to review the scientific literature published between 1979 and 2010 on the working conditions and health impacts associated with tobacco cultivation, with particular emphasis on the Brazilian context.

\section{Methods}

A search of the literature documenting the working conditions and the impact of tobacco cultivation on human health was performed in the PubMed, Scopus, WilsonWeb (Biological \& Agricultural Index Plus, Social Sciences Full Text), and Virtual Health Library (BVS) - Public Health (Bireme/PAHO) databases between July 20 and 28, 2010.

We searched for studies analyzing the impact of tobacco cultivation on human health and the cultural, social, and economic implications of tobacco production. The following search terms were used: tobacco, rural worker health, agricultural worker disease, working conditions, unsafe working conditions, occupational disorders, labor force. In Scopus, these terms were inserted in the fields "article title," "abstract," and "keyword." The combination of search terms was adapted to optimize results and to reflect the specific characteristics of each database: two are based on search terms (PubMed and BVS) and two on search engines (Scopus and WilsonWeb), that is, the keywords are located within the text instead of being matched to subject headings. After the first search round, a large number of articles focused on health problems resulting from tobacco consumption was retrieved. We then chose to add Boolean operators AND and NOT to exclude the headings "cancer" and "smoking."

The final search strategy was: in PubMed, ["agricultural worker disease" OR "working conditions" OR "occupational risks" AND "tobacco" NOT "cancer" NOT "smoke" NOT "smoking"]; in BVS - Public Health, [doença dos trabalhadores agrícolas AND tabaco (agricultural worker disease AND tobacco)]; Scopus, [your query: (TITLE-ABS-KEY("agricultural worker disease" OR "occupational disease") OR TITLEABS-KEY("working conditions" OR "occupational risks" OR "labor force") AND TITLE-ABS- 
KEY("tobacco") AND NOT TITLE-ABS$\mathrm{KEY}\left(\right.$ cancer OR neoplasm* OR smok $\left.{ }^{\star}\right)$ )]; WilsonWeb, [(agricultural worker disease OR work conditions OR occupational risks OR occupational disease OR working conditions OR labor force) $<$ in $>$ Smart Search AND tobacco $<$ in $>$ Smart Search NOT (cancer OR neoplasm* OR smok ${ }^{\star}$ ) $<$ in $>$ Smart Search In Biological \& Agr Index Plus, Social Sciences Full Text]. These strategies yielded 120 articles that were closer to the topic of interest published between 2000 and 2010. To increase the number of articles of interest, the search period was extended to include articles published between 1979 and 2010. The frequency of articles published on the theme grew steadily from 1979 onwards, This expanded search strategy yielded 214 papers in English, Spanish, and Portuguese.

\section{Results}

Of the 214 references initially identified, 78 were excluded after review of the titles and abstracts (if available) or else because the language of publication was not English, Spanish, or Portuguese. That step yielded 136 articles. These were read, and an additional 63 papers were excluded because they covered populations of agricultural workers not working with tobacco or dealt with biochemical analyses of the tobacco plant; 36 duplicate references were also excluded. Of the remaining 37 articles, 13 were not available through the databases, and were located using the Interlibrary Loan System of Brazil (COMUT).

Taking into consideration the importance of Brazil in the worldwide scenario of tobacco production and the fact that only one study conducted in Brazil was retrieved by our search, we decided to review reports and other documents published by the Brazilian Ministries of Health and Agricultural Development, both strongly involved with health, economic, and social issues related with tobacco production. These documents were retrieved from government web sites and commonly made reference to other studies conducted in Brazil and covering the topics listed above, which in turn were also included in our review. The reference lists of these articles were hand-searched and 34 additional articles of interest were identified, 11 from Brazil and 23 from other countries (Figure 1).

The data retrieved from the databases included in our search were classified according to an analytical matrix including categories such as study design, thematic axis, and country where the study was carried out (Table 1). The follow-

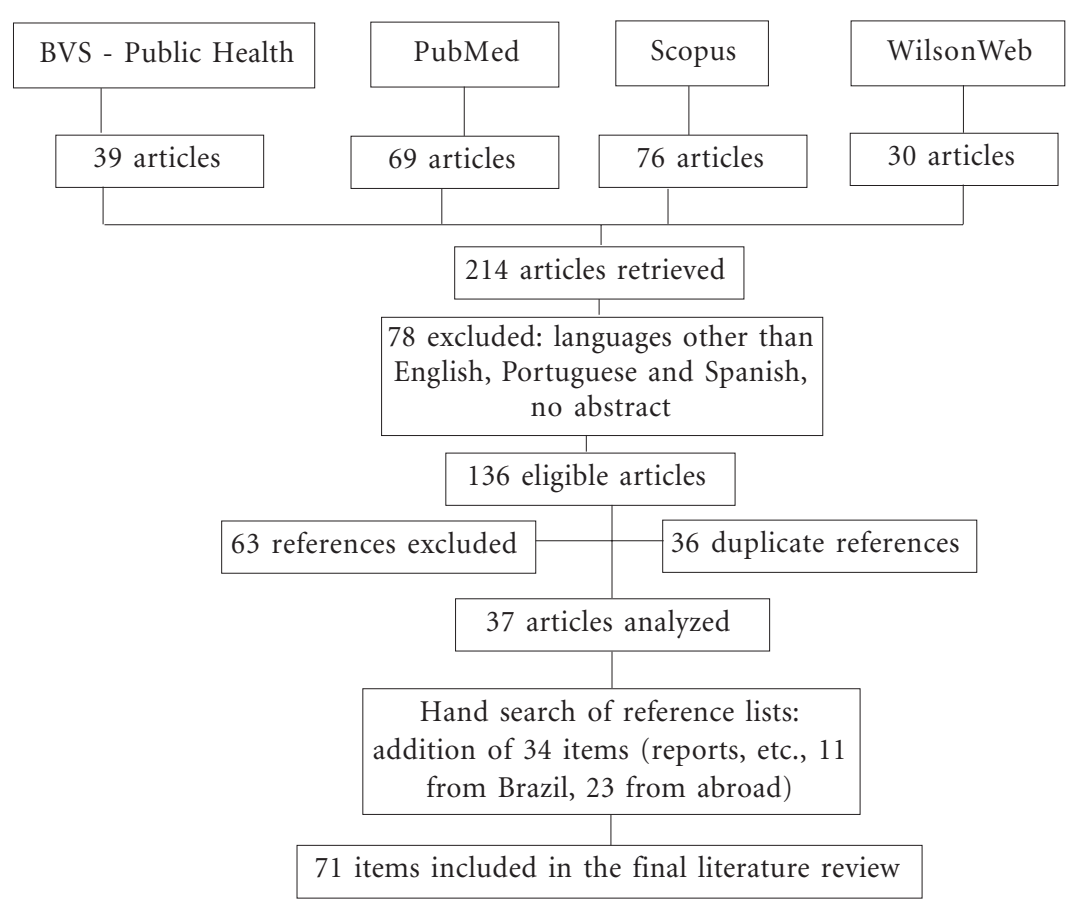

Figure 1. Literature review: search strategy, period 1979-2010 


\begin{tabular}{|c|c|c|c|c|c|}
\hline \multirow{28}{*}{ 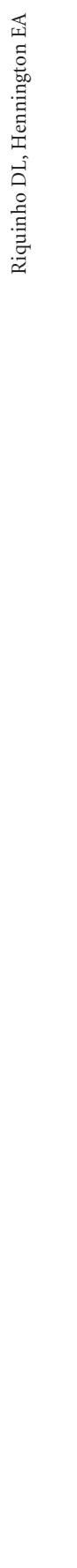 } & Table 1. Type of a & ticle, thema & c axis, and country where the study was & carried out, period 1979 & 2010. \\
\hline & Type of study & $\begin{array}{l}\text { No. of } \\
\text { articles }\end{array}$ & Thematic axis & $\begin{array}{l}\text { Country where study } \\
\text { was carried out }\end{array}$ & $\begin{array}{l}\text { Reference } \\
\text { number }\end{array}$ \\
\hline & Epidemiological & $23(62 \%)$ & $\begin{array}{l}\text { Social and economic implications for } \\
\text { health }\end{array}$ & Vietnam & 31 \\
\hline & & & Acute and chronic health effects & India & 51 \\
\hline & & & GTS - migrant and seasonal workers & USA & 35,44 \\
\hline & & & GTS - dermal exposure & USA & $\begin{array}{c}40,41,42,43 \\
47,63\end{array}$ \\
\hline & & & $\begin{array}{l}\text { Neurobehavioral and } \\
\text { neurophysiological changes }\end{array}$ & Malaysia & 18 \\
\hline & & & GTS - shade-tobacco & USA & 52,53 \\
\hline & & & $\begin{array}{l}\text { Working conditions and respiratory } \\
\text { diseases }\end{array}$ & Zimbabwe & 62 \\
\hline & & & Bone and muscle injuries & USA & 65 \\
\hline & & & GTS - space-time relationship & USA & 28 \\
\hline & & & GTS - Epidemiological patterns & USA & 61 \\
\hline & & & GTS - Health conditions & India & 56,64 \\
\hline & & & Neuropsychiatric changes & Brazil & 68 \\
\hline & & & $\begin{array}{l}\text { Systemic exposure to nicotine in } \\
\text { tobacco (harvesters) }\end{array}$ & Italy & 45 \\
\hline & & & Family agriculture & Malawi & 11 \\
\hline & & & Exposure in various types of crops & USA & 39 \\
\hline & Case study & $5(14 \%)$ & GTS & Poland & 36,58 \\
\hline & & & Alternatives to the use of pesticides & Cuba & 70 \\
\hline & & & Contact dermatitis & USA & 48 \\
\hline & & & GTS - medication & USA & 19 \\
\hline & Literature review & $2(5 \%)$ & Social and health effects & USA & 15 \\
\hline & & & GTS - children and adolescents & USA & 8 \\
\hline & $\begin{array}{l}\text { Qualitative } \\
\text { research }\end{array}$ & $7(19 \%)$ & $\begin{array}{l}\text { Workforce in globalized crops such as } \\
\text { tobacco }\end{array}$ & USA & 1 \\
\hline & (Oral histories, & & Regulation of tobacco products & USA & 12 \\
\hline & $\begin{array}{l}\text { ethnography, } \\
\text { essays) }\end{array}$ & & $\begin{array}{l}\text { Replacement of women workers } \\
\text { following World War II }\end{array}$ & & 13 \\
\hline & & & $\begin{array}{l}\text { Violence against rural migrant } \\
\text { workers }\end{array}$ & USA & 14 \\
\hline & & & $\begin{array}{l}\text { Immigration and tobacco production } \\
\text { GTS - concepts }\end{array}$ & Bolivia & $\begin{array}{c}26 \\
49,50\end{array}$ \\
\hline
\end{tabular}

ing study designs were considered: epidemiological (ecological, cross-sectional, cohort, case-control, or experimental); literature review; clinical case study; and qualitative approaches, including oral history, ethnography, and essays.

Most research was carried out in the United States, and most studies were of an epidemiological nature, focusing on nicotine poisoning (green tobacco sickness, GTS) and dermal exposure. We found the topic to be largely unexplored in Bra- zil. Exceptions are the Ministry of Health, through the National Cancer Institute, the University of Santa Cruz do Sul, in southern Brazil, the Department of Agricultural and Socioeconomic Studies associated with family agriculture organizations in Curitiba, in the southern state of Paraná, and more recently the Ministry of Health Secretariat of Health Surveillance. Most scientific investigation has focused on diseases associated with tobacco growing, especially GTS. 


\section{Tobacco production in Brazil and the world: an overview}

The world's foremost producer of tobacco is China, followed by Brazil, India, the United States, and Malawi ${ }^{8}$. Since tobacco consumption is high in China, most of that country's production is aimed at the domestic market ${ }^{4,9}$, making Brazil the largest exporter of leaf tobacco, followed by Zimbabwe and Malawi. Most production in Brazil - 92.7\% - is concentrated in the South. The North contributes with $7.3 \%$. Of the southern states, the largest producer is Rio Grande do Sul.

The average size of tobacco farms in the South of Brazil in 2009/2010 was 41.51 acres, with $35.13 \%$ between 2.47 and 24.7 acres, $25.4 \%$ between 27.18 and 49.42 acres, and $1 \%$ with 50 or more acres ${ }^{10}$. In the United States, tobacco farms are usually close to 247.10 acres, vs. 3.71 acres in Malawi ${ }^{11,12}$.

Concerning the workforce, historically, women have played a major role in the cultivation of tobacco, especially in the United States. In the $17^{\text {th }}$ century, European women were hired to work in tobacco plantations alongside men. In the $18^{\text {th }}$ century, female African slaves and their daughters predominated in these farms. In the end of the $19^{\text {th }}$ century and beginning of the $20^{\text {th }}$ century, a profound change in tobacco production took place, with cultivation shifting to small, familyowned properties, which promoted the participation of women in all stages of production, from cultivation to marketing. In the $21^{\text {st }}$ century, this workforce was gradually replaced with mechanized agriculture and male seasonal workers, especially Latino migrants ${ }^{13}$.

An anthropological study ${ }^{1}$ shows that the tobacco workforce in the United States has been usually constituted by "others" - women, blacks, migrants - and is now characterized by a "globalized labor force." The maintenance of this status was made possible by the international economic restructuring, which has translated into wide availability of migrant populations in the U.S ${ }^{14}$.

In Brazil, tobacco is usually grown in small family farms ${ }^{10,11}$. According to the Brazilian Association of Tobacco Growers ${ }^{10}$, around 90\% of workers employed in tobacco fields are related to the owners of these properties, with temporary workers making up the remaining $10 \%$. It should be noted that child labor is observed in all countries with family-operated tobacco farms, with children working full time or during non-school hours, participating in the entire cultivation process ${ }^{3,8}$.

The cultivation of tobacco in developing countries is physically demanding, with manual handling of heavy loads and application of a variety of pesticides in different stages, such as sprayed methyl bromide (herbicide, insecticide, fungicide, and nematicide) during seedling production, disulfoton (organophosphate insecticide and acaricide) following sowing and transplantation, and imidacloprid (nitroguanidine insecticide) and acephate (organophosphate insecticide and acaricide) for pest control until harvest. It is well known that the use of these products causes various health problems and environmental damage damage $e^{3,15-18}$.

Among the health problems related to tobacco farming, the most noteworthy are GTS, respiratory and musculoskeletal problems, and mental disorders resulting from the exposure to pesticides. GTS, the best documented condition, is usually felt during the harvest, resulting from the dermal exposure to tobacco leaves that causes acute nicotine poisoning. Symptoms include nausea, vomiting, headache, and abdominal cramps $^{19-21}$. Respiratory effects are caused by tobacco dust, especially during processes such as curing, but they have not been extensively studied. The musculoskeletal problems described in the literature are mostly related to labor injuries $^{22,23}$. The occurrence of mental disorders such as chronic depression and suicide suggests a role of organophosphate pesticides ${ }^{18,24}$.

Concerning environmental damage, pesticides are a major source of soil and water contamination. In addition, as a crop, tobacco quickly drains the soil, requiring a higher amount of nitrogen, phosphorus and potassium than other crops. The impact of depletion is higher in tropical countries, where the level of nutrients in the soil is lower. This explains why this crop requires intensive use of fertilizers ${ }^{25}$.

\section{Production characteristics and working conditions}

Traditionally, tobacco was produced in the United States with government subsidy and sold at public auction. After being graded for quality standards by the United States Department of Agriculture (USDA), tobacco leaves were sold in warehouses to buyers (tobacco manufacturers or leaf dealers) at prices that fluctuated during the selling season. More recently, this system was replaced with a regimen of direct contracting between manufacturers and farmers ${ }^{12}$, which challenges the Jeffersonian notion of independence ${ }^{1,12}$.

In Argentina and Malawi, sharecroppers have been reported to work in tobacco fields (Bolivi- 
ans working as sharecroppers in the province of Jujuy, Argentina, and local families in Malawi) ${ }^{11,26}$. Sharecroppers represent a cheaper workforce and the transfer of production risks from landowners to the workers themselves ${ }^{26}$.

The tobacco production network, Brazil included, is transnational and based on a direct link between producers and the industry, through an "integrated system." This system relies on a sales-purchase agreement between farmers and the industry. The tobacco industry is responsible for the dynamics and innovation in agricultural production and has exclusive rights to sell inputs, as well as the right to purchase the final product $^{4,12,27}$.

Three types of tobacco are grown in Brazil: Virginia, Burley, and common tobacco. In the South, $82.7 \%$ of the tobacco produced is of the Virginia type, with $16.4 \%$ Burley and $0.9 \%$ common tobacco'. In Malawi, Burley is the most common variety ${ }^{11}$. In the United States, the most common tobacco types are Virginia, used in the manufacture of cigarettes, and a variety of air-cured Burley used for chewing and also in the manufacture of cigarettes. The regions where these products are cultivated depend on many factors, including topography, soil and climate conditions, and historical aspects ${ }^{13}$.

In Brazil, the tobacco production cycle starts in May. A float system is used to produce transplants, using polystyrene trays covered in plastic, which workers call "swimming pools." In August and September the plants reach transplant size. At this stage, large amounts of pesticides are used. The harvesting of leaves starts between December and February, around 60 days later. Between transplantation and harvesting, farmers monitor growth, carry out pest and disease control, and remove flowers (top the plants) to ensure heavier and higher quality leaves ${ }^{9,17,28,29}$.

The lack of personal protective equipment, including masks, gloves, and boots, due to the high cost of this equipment or to the fact that it is not adapted to a tropical climate, makes agricultural workers vulnerable to acute and chronic poisoning caused by pesticides applied during different stages of the tobacco production process, mostly organophosphate agents agents s. $^{17,25}$.

Virginia tobacco is harvested in stages. The lower leaves, which are larger and older, are picked first, and the upper leaves, last. After harvesting, the leaves are strung onto sticks and dried in curing barns (flue-cured tobacco) ${ }^{15}$. Burley and common tobacco ripen more evenly and do not require two-stage harvesting. These two types of tobacco also differ from Virginia in terms of the curing process, which is done in well-ventilated areas (air cured) ${ }^{15}$. After curing, the leaves are baled or sheeted according to class and stored until transport to industry warehouses ${ }^{9,13}$. Tobacco leaves from Brazil are internationally recognized for their high quality and low price. Three main factors underlie this reputation: the absence of mechanization resulting from the high cost of machinery and/or cultivation in steep or rocky soil and a workforce of families ${ }^{30}$.

Also noteworthy is the fact that tobacco represents $70 \%$ of the income of families involved with tobacco, and tobacco growers have tobacco as their main income source ${ }^{10}$. Other agricultural activities, if any, are basically for subsistence; other products are sold only if there is surplus production. This makes farmers dependant on the tobacco industrial production chain, preventing agricultural diversification ${ }^{11,13}$.

The grading of tobacco by the industry for marketing purposes has resulted in a competitive environment that leads farmers to sell at an increasingly lower price. Whereas a few large-scale growers have become rich, many small growers are having trouble with a crop that involves physically demanding work and investment in various resources, and that is associated with dangers to health and the environment resulting from exposure to pesticides and nicotine poisoning, placing at risk all those involved, especially women and children ${ }^{4,13,31}$.

The tobacco productive chain is a complex oligopoly, in which a few companies control the market, the supply/demand balance, and the modes of production. The vertical relationship that these companies establish directly with farmers decreases the grower's productive and economic autonomy, resulting in working conditions that are inadequate and unhealthy, with negative impacts on health and environment. A summary of the tobacco productive chain and the type of organization and workforce involved in tobacco growing is shown in Table 2.

\section{Main health problems associated with tobacco production}

The production of tobacco causes short and long-term effects on human health. The recognition of such risks is not recent. In 1713, Bernardino Ramazzini recorded various symptoms, including headache and abdominal cramps, among Italian workers and attributed these symptoms to exposure during tobacco cultivation ${ }^{32}$. In ad- 
dition to the symptoms that characterize nicotine poisoning, there are respiratory and musculoskeletal impacts resulting from exposure to pesticides. Table 3 presents a summary of the main health and environmental issues associated with tobacco production and strategies for facing this problem available in Brazilian public policies, as reported in the literature.

\section{Green tobacco sickness (GTS)}

GTS was first described as a specific disease affecting rural tobacco workers in Florida in $1970^{33}$. It is caused by stimulation or inhibition of cholinergic receptors in the central nervous system, leading to a clinical presentation that is often characterized by vomiting, nausea, dizziness and headache. Additionally, abdominal

Table 2. Summary of the characteristics of tobacco production and of the workforce involved in tobacco growing according to a review of the literature, 1979-2010.

\begin{tabular}{|c|c|c|}
\hline System of production & Country & Reference number \\
\hline Government subsidy and sold at public auction & USA & 1 \\
\hline Integrated system & USA, Brazil & $1,12,27$ \\
\hline Organizational structure/workforce & Country & Reference number \\
\hline Sharecropping & Argentina and Malawi & 11,26 \\
\hline Family agriculture & Brazil and Malawi & 26 \\
\hline Latino migrants & USA & 13 \\
\hline Types of tobacco & Country & Reference number \\
\hline Virginia, Burley & USA, Brazil, Malawi & $9,11,13$ \\
\hline \multicolumn{3}{|l|}{ Processing } \\
\hline Flue-cured (Virginia) & $\begin{array}{l}\text { Crop is harvested in stages. After } \\
\text { the harvest, leaves are strung onto } \\
\text { poles and cured in hothouses }\end{array}$ & 15 \\
\hline Air-cured (Burley) & $\begin{array}{l}\text { Crop is harvested at once. Leaves } \\
\text { are air-dried }\end{array}$ & 15 \\
\hline Float system & $\begin{array}{l}\text { Seedlings are transplanted } 60 \text { days } \\
\text { after sowing. Pest and disease } \\
\text { control requires intensive pesticide } \\
\text { use. Harvest takes place within } 60 \\
\text { days. }\end{array}$ & $9,17,25,28$ \\
\hline
\end{tabular}

Table 3. Summary of the main health issues associated with tobacco production and Brazilian public policy strategies for facing these issues, according to a review of the literature, 1979-2010

\begin{tabular}{lll}
\hline \multicolumn{1}{c}{ Health issue } & \multicolumn{1}{c}{ Symptoms and signs / associated conditions } & \multicolumn{1}{c}{ Reference number } \\
\hline Green tobacco sickness (GTS) & Vomiting, nausea, dizziness, headache, abdominal & $20,34,35,37,38,48$, \\
& pain, diarrhea, abnormal blood pressure and heart rate & $49,52,56,57,58,59,60$ \\
& Visual complaints & 36 \\
Respiratory problems & Worsening pulmonary function, increased risk of & $62,63,64$ \\
& emphysema & \\
Musculoskeletal lesions & Trauma, various injuries & $1,22,23,65$ \\
Pesticide poisoning & Altered nerve conduction velocity, postural sway, & $66,67,68$ \\
& parkinsonism and depression & \\
& Acute and chronic toxicity due to the various products & 17,25 \\
& used during tobacco growing. Organophosphate & \\
& poisoning is predominant & \\
& Public policy strategies
\end{tabular}

Government support of economically viable alternatives to tobacco growing (including 27 support programs and credit provision)

Development of a specific surveillance system to monitor the health of rural tobacco $\quad 37,38$ workers 
cramps, diarrhea, changes in blood pressure and heart rate may also occur during or after exposure to Nicotiana tabacum found in tobacco leaves $^{20,34,35}$. In Poland, visual changes have also been described in association with other GTS symptoms $^{36}$. Two studies conducted in Brazil found reports of GTS among tobacco workers in the North region (Arapiraca, state of Alagoas, in 2007) and in the South of the country (Candelária, Rio Grande do Sul, in 2008) by means of a descriptive epidemiological study followed by a case-control study ${ }^{37,38}$. The symptoms most commonly reported by affected workers were nausea, vomiting, headache and dizziness. Nonsmokers were affected most severely. Contradicting previous reports from other countries, exposure to wet leaves was not associated with increased risk of $\mathrm{GTS}^{37,38}$.

During the harvest, the body of tobacco workers is surrounded by tobacco plants and potentially exposed to nicotine. Leaves are often held by workers underneath their arms. Dermal absorption of nicotine increases if the leaves are damp, and may be facilitated by preexisting lesions in the hands and armpits. Gloves and water-resistant clothing may prevent this, but most of the time such protective gear is not worn because it makes harvesting more difficult ${ }^{20,39-48}$.

In the United States, Latino migrants are considered to be most vulnerable to GTS. These workers are frequently inexperienced, do not communicate well in English, and do not have health insurance. They may also be illegal immigrants, and may thus be afraid to leave work and seek health care. This encourages self-medication in the presence of GTS symptoms ${ }^{28,42,49,50}$.

The consequences of acute and chronic exposure to nicotine for the health of men and women involved in the cultivation of tobacco have been reported by a study that identified a greater prevalence of hypertension and premature deliveries in this population as compared to a control group. However, according to the authors, these differences were not statistically significant, possibly because of the size of the sample, absence of comparative studies, and differences in the amount of nicotine absorbed during the various stages of tobacco cultivation ${ }^{43,51}$.

Some studies have assessed GTS symptoms and nicotine levels absorbed from shade tobacco leaves based on salivary levels of cotinine among agricultural workers from Connecticut, U.S. The authors found a low risk of nicotine dermal absorption and a low incidence of GTS in the sample assessed, suggesting that shade tobacco may exhibit lower levels of nicotine when compared with either Burley or Virginia tobacco ${ }^{52,53}$.

The main differential diagnoses of GTS are pesticide poisoning or heat exhaustion. Pesticide poisoning usually occurs at the start of the harvest season, since the last spraying is usually done a few weeks earlier ${ }^{48,54}$. In contrast to GTS, workers with heat exhaustion have fever and do not present increased levels of cotinine, a nicotine metabolite. In addition, GTS symptoms may also appear in rainy days, when heat exhaustion is less likely ${ }^{34}$.

It is estimated that $86 \%$ of the nicotine absorbed by the body is biotransformed into cotinine, the main metabolite of nicotine, with a halflife of around 20 hours ${ }^{55}$. Urinary cotinine levels, which correlate significantly with the total amount of nicotine absorbed, are used to monitor environmental exposure to tobacco and evaluate the degree of poisoning ${ }^{56,57}$. Despite its nonspecific symptoms, GTS can be diagnosed if correlated with tobacco farming. In addition, the measurement of cotinine levels may help establish a differential diagnosis ${ }^{48,58}$.

A study with tobacco workers in Malaysia ${ }^{59}$ reported significantly increased levels of urinary cotinine among nonsmokers, suggesting greater absorption of nicotine from tobacco leaves. Smoking cigarettes is a strategy known to increase tolerance to the signs and symptoms associated with tobacco poisoning ${ }^{49,52}$. Among smoking workers, the incidence of GTS was lower (incidence density of 2.39 vs. 1.8 days/days worked $)^{60}$.

The occupational health risks associated with nicotine absorption in tobacco workers are a reason for concern. In addition to the handling of leaves, the strategy of smoking makes these workers more susceptible to other problems associated with tobacco, as well as to the consequences of smoking. Monitoring and reporting of suspected cases to surveillance systems is necessary so that the magnitude of the problem can be determined and its economic impact on the healthcare system and on the productivity of tobacco workers, taking into account work days lost, can be measured ${ }^{61}$.

\section{Respiratory problems}

As previously mentioned, little information is available in the literature concerning the respiratory problems associated with tobacco cultivation. The exposure of workers to dust from dry tobacco leaves, resulting from the curing process, which concentrates nicotine and other chemical substances likely to cause damage to the res- 
piratory system, especially when personal protective equipment is not worn ${ }^{15,62}$. Respiratory exposure also occurs during stacking, when the leaves are tied; when leaves are loaded for transportation; and during the mixing and spraying of chemicals ${ }^{63}$.

Pulmonary function tests in workers exposed to tobacco dust and other types of workers revealed a increased risk of emphysema in the former, even among nonsmokers ${ }^{62,64}$. The ability of the highly vascularized respiratory system to absorb minute particles makes it especially vulnerable to irreversible respiratory problems in both smoking and non-smoking tobacco workers.

\section{Musculoskeletal lesions}

A study carried out in a university hospital in Kentucky, U.S., with the objective of determining the incidence of musculoskeletal injury related to tobacco farming, showed that 23 out of 24 persons with farm-related injuries during the study period were tobacco workers ${ }^{22}$. Seventeen (74\%) of these workers were injured in falls from tobacco-drying barns, and 18 (75\%) had skeletal injury. The authors propose that extreme heat and poor design or maintenance of barns contributed to the high incidence of falls ${ }^{22}$.

A review of emergency admissions in three locations in Kentucky ${ }^{23}$ revealed that $23 \%$ of injuries were related to tobacco production, not including GTS. Thirty percent were caused by falls, $27 \%$ were related to cutting and piercing, and $13 \%$ were related to overexertion. More than $90 \%$ of the injured workers required outpatient monitoring. Still in the state of Kentucky, a population-based study investigated the occurrence of nonfatal agricultural injuries in farmers older than 55 years of age, having reported a yearly overall crude injury rate of 9.0 per 100 injured farmers. Farms with beef cattle and tobacco came second (after farms with beef cattle alone) in terms of the number of injuries ${ }^{65}$. By restricting their sample to this age range, the authors focused on the ability of older farmers to carry out the routine activities of agriculture and the possibility of increased vulnerability due to the sensorimotor losses associated with aging ${ }^{65}$. Tobacco production also predisposes to other injuries associated with tractor overturns, use of knives to cut stems, and falls from the high drying and storage barns ${ }^{1}$.

\section{Pesticide poisoning}

Chemical products used in tobacco fields are usually applied by hand or using acrylic back- pack sprayers. In the absence of protective gear, this may cause exposure to concentrated doses of pesticides that can be absorbed through the mouth and skin or inhaled ${ }^{15,16,63}$. Because of that, pesticides are often applied by children younger than 15 years of age, who are more tolerant to these effects ${ }^{16,24}$. Although this tolerance is mentioned in the cited literature, the reasons behind it are still unclear, which is indicative of the research gap regarding this topic, particularly in this population.

A study assessing the size and effect of exposure to organophosphates and carbamates in children working in or accompanying their parents to tobacco fields in Nayarit, Mexico, did not find a difference in terms of acetylcholinesterase levels in working and nonworking children living close to the fields $s^{66}$. Hemoglobin measurements showed that $93 \%$ of children were anemic. Those authors have stated that the problem may be larger than initially thought, since the population surrounding tobacco fields also seems to be affected through generalized environmental contamination, including contamination of drinking water sources, due to pesticide runoff ${ }^{66}$.

The effects on the central and peripheral nervous system resulting from exposure to pesticides commonly used in tobacco plantations, such as organophosphates, carbamates, and dithiocarbamates, were examined in 76 tobacco growers and 38 sex- and age-matched controls in Kelantan, Malaysia ${ }^{67}$. Speed of nerve conductance and postural oscillations appeared to be sensitive indicators of the effects of these products on the peripheral and central nervous system ${ }^{67}$. All the workers analyzed had a significant decrease in serum cholinesterase activity as compared to controls.

A study was carried out to evaluate clinical, psychiatric, and extrapyramidal symptoms in addition to plasma acetylcholinesterase activity in a sample of 37 workers involved in family agriculture of tobacco in the South of Brazil. These farmers had been chronically exposed to organophosphates. Tests were carried out on two occasions: during a three-month period of pesticide exposure and after three months without exposure. The results showed that acetylcholinesterase activity was normal in all subjects, with no differences between the periods during or following exposure. Clinically significant extrapyramidal symptoms were present in 12 out of 25 individuals. Tremor was the predominant sign, followed by masked facies and reduced arm swing (characteristic signs of parkinsonism). 
According to the authors, the findings support the need for parameters other than acetylcholinesterase activity to monitor the chronic consequences of low-dose exposure to organophosphate pesticides, and suggest that exposed workers may develop permanent extrapyramidal symptoms in addition to transient motor and psychiatric impacts, such as symptoms and signs of clinical depression and parkinsonism ${ }^{68}$.

\section{Environmental problems} resulting from tobacco production

An ethnographic study carried out in the Copán River valley, Honduras ${ }^{16}$, described the social and ecologic impacts of the production system used for Virginia tobacco, which is dried in warm air, including deforestation and exposure to pesticides. Flue-cured tobacco requires a considerable amount of wood, with potential for significant deforestation. Even though the agreement between the tobacco industry and farmers contemplates reforestation efforts with seedlings provided by the industry (mostly leucaena and eucalyptus), the results are limited by the great requirement for fuelwood in the region. Exposure to pesticides also occurs when spraying equipment is cleaned and through the disposal of packaging in rivers and streams. The presence of pesticides was mentioned by study participants as a possible cause of fish and bird mortality ${ }^{16,69}$.

Similar effects are described in a study carried out in Nicaragua ${ }^{69}$ to analyze the intensive use of pesticides in tobacco farming and the possible environmental consequences thereof. Since most tobacco farms are located close to important rivers in the department of Nueva Segovia, there is contamination of both the superficial aquifer and deep groundwater with pesticides. The strong rains occurring in the region also contribute to the dissemination of toxic residues deposited on the soil following multiple sprayings. Soil fertility in these areas is decreased, and the use of fertilizers and pesticides in a monoculture system contributes to speed the degradation, with loss of groundcover ${ }^{69}$. In Cuba, a program to reduce the dependence on pesticides was developed for crops such as sugar cane, citrus, tobacco, corn, and vegetables ${ }^{70}$. The program relies mainly on expanding the knowledge of Cuban agro-ecology in order to implement cultural control practices, research and implementation of biological pest control, and research on plant resistance and development of resistant crop varieties.

Most pesticides used in the various stages of tobacco production are classified as environmental hazards and are extremely toxic to fish and birds, as is the case of mancozeb, endosulfan, and zineb ${ }^{69,71}$. The use of these products is restricted or banned in Central America, the U.S., and Sweden ${ }^{15,69}$.

\section{WHO Framework Convention on Tobacco Control: challenges and strategies for Brazilian public health}

The social, health, and environmental consequences related to the production of tobacco, as previously described, together with the increase in the number of smokers in developing countries, especially among women and the young, and the role played by advertising in stimulating smoking are some of the issues that led to approval of the WHO FCTC ${ }^{3,4,7}$. This treaty focuses on demand reduction strategies as well as supply issues. The final version of the FCTC includes 38 articles proposing price and tax and non-price measures meant to reduce the demand for tobacco, including reduced availability of tobacco, environmental protection, issues relating to accountability, technical-scientific cooperation and exchange of information, institutional mechanisms and financial resources, in addition to measures for conflict resolution through mediation and conciliation of parties ${ }^{7}$.

The tobacco industry is paying close attention to this changing scenario and has launched a broad television and print media campaign concerning the risks of smoking. These strategies depict tobacco manufacturers as "citizen companies" that are responsible for their products and guide consumption in a responsible manner. In the United States, for example, Philip Morris has introduced a cigarette brand made with tobacco produced with impurity-free tobacco grown with a lower pesticide load, containing only tobaccorelated components ${ }^{12}$. The farmers linked to this enterprise get the best price for their tobacco. However, there are many strict requirements for production, and failure to meet these may allow the agreement to be broken ${ }^{12}$.

Article 17 of the FCTC alludes to the situation of tobacco growers and workers, recommending that intergovernmental, international, and regional organizations cooperate to promote economically viable alternatives to replace tobacco as a crop. Article 18 refers to the protection of the environment and of the health of persons involved in tobacco farming and tobacco product manufacture ${ }^{7}$. The FCTC underscores the 
strong relationship between local and global determinants: local problems resulting from tobacco farming and consumption have been considered globally, without losing sight of specificities, requiring the creation and application of alternatives that do not preclude government support at all levels.

A part of the investment previously allocated for tobacco in the United States has been reallocated to help farmers adapt and switch to new crops $^{1}$. However, some barriers to diversification have been identified, such as market access and the need to acquire specialized and operational knowledge to invest in new equipment ${ }^{12}$. Farmers who are successful with agricultural diversification have higher levels of educational achievement and more stable access to migrant groups for work, in addition to a relatively large expansion of arable land ${ }^{12}$.

In the South and North regions of Brazil, economically viable alternatives to tobacco farming are being implemented with support from the government (qualification programs and financing) and religious institutions ${ }^{27}$. However, this experience is largely limited as compared to the extent of tobacco cultivated land and tobacco profitability. Despite the controversy, growing tobacco allows thousands of small producers to make ends meet, as tobacco farming is more profitable on a per-hectare basis than cultivation of other crops, such as beans or corn.

Regarding health surveillance and protection in rural workers involved in tobacco production, the Brazilian Ministry of Health Secretariat of Health Surveillance team recommended prevention and control measures based on local actions meant to build awareness of the toxic effects of tobacco leaves among professionals and the general population, providing guidance to health care services for notification of cases of poisoning to the Brazilian Infectious Disease Reporting System, SINAN $^{37,38}$. Recommendations were also made to the State Health Department and to the Ministry of Health Secretariat of Health Surveillance. The State Department undertook the task of training municipal health professionals to communicate and analyze cases of external poisoning. The Secretariat of Health Surveillance agreed to design studies for analysis of the population exposed to tobacco farming and to determine the prevalence of GTS in different populations, in addition to preparing the Workers' Health Referral Center (CEREST) to monitor this disease ${ }^{37}$.

If on the one hand these are commendable initiatives, on the other hand they clearly point to the challenge of identifying occupational diseases other than GTS in tobacco workers, through biomarker-based monitoring of pesticide exposure and contamination and its effects on adults, pregnant women, and children in both the short and the long term. Also challenging is the detection of respiratory disease, musculoskeletal injury resulting from overexertion, repetitive movements and occupational accidents, as well as the identification of environmental repercussions such as water and soil contamination. In Brazil, in the occupational health environment, it is essential that quantitative studies be developed to identify the scenario of morbidity, mortality and incapacity relating to the cultivation of tobacco, and also qualitative studies that contribute to the understanding of social, cultural, and economic phenomena associated with the productive chain in different realities, focusing on the daily routine of these workers and on their strategies to overcome the difficulties and problems related to the production of tobacco.

\section{Final remarks}

This study sought to present and discuss the working conditions and health impact of tobacco cultivation through a review of the literature. A worldwide trend toward standardization of the production process of tobacco was observed, especially concerning the establishment of a direct agreement between the industry and the farmer. Whereas in the U.S. the production of tobacco has been carried out by "others" - European women, African Americans, and more recently male Latino migrants -, in developing countries the workforce is constituted by families. However, with the changes in family structure, especially resulting from the decline in fertility rates, including in rural Brazil, the question remains of how tobacco production will be organized in the future - whether there will be a reduction in this crop or a shift towards the hiring of daily workers with worse working conditions, considering that mechanization is limited and a significant number of workers is required. The treatment of diseases and injuries burdens the health care and social welfare systems, especially when lost workdays are involved. In the context of family agriculture, the absence of one family member may translate into economic loss and overburden other family members.

Another important aspect is the need for studies on the tobacco productive chain. Considering 
the extension of the cultivated land, the number of workers involved, the vulnerability and potential risks to human and environmental health, the amount of research on this topic is still lacking, and most of it is still restricted to specific geographic areas and health effects. On the contrary, tobacco research should be a part of the public health research agenda in Brazil, viewed as a cross-sector challenge involving the ministries of health, environment, land reform, and labor. Interventions will have to contemplate different areas of knowledge that become interrelated when tobacco production is discussed, for example, health, economy, and agricultural studies. In terms of specific challenges, the field of occupational health has the important tasks of empowering rural workers and promoting social control through educative practices that provide clear information on the occupational risk and vulnerability resulting from tobacco production, as well as of evaluating, controlling, and monitor- ing, through health surveillance, the exposed populations and environments.

The FCTC is an important stepping stone for the mobilization of the Brazilian government and society to face the consequences of tobacco production and consumption. It is necessary that the problems associated with tobacco be addressed both globally and locally; micro and macroeconomic factors must be weighed and balanced by encompassing public policies, with attention to the historical and sociocultural aspects influencing the life and health experiences of tobacco growing families.

Finally, one limitation of the present study is the absence of descriptions of the tobacco production process in countries other than Brazil. This is due in part to the small number of published articles on this topic, and also possibly to the exclusion of articles published in languages other than Portuguese, Spanish, or English.

\section{Colaboradores}

DL Riquinho worked in the design of the article, methodology, research and in the writing final and EA Hennington participated in all stages of work directing and reviewing the paper.

\section{Referências}

1. Kingsolver AE. Farmers and Farmworkers: two Centuries of Strategic Alterity in Kentucky's Tobacco Fields. Critique of Anthropology 2007; 27(1):88-102.

2. Food and Agriculture Organization. Issues in the global tobacco economy: selected case studies. Commodities and Trade Division, Raw Materials, Tropical and Horticultural Products Service. Commodity Studies $n^{\circ}$. 2. Rome: Food and Agriculture Organization; 2003

3. Brasil. Ministério da Saúde. Secretaria de Atenção à Saúde. Instituto Nacional de Câncer (INCA). A ratificação da Convenção-Quadro para o Controle do Tabaco pelo Brasil: mitos e verdades. Rio de Janeiro: INCA; 2004.

4. Brasil. Ministério da Saúde. Secretaria de Atenção à Saúde. Instituto Nacional de Câncer (INCA). Tabaco e pobreza: um círculo vicioso. Rio de Janeiro: INCA; 2004.

5. World Health Organization. Tobacco increases the poverty of individuals and families, 2004. [cited 2009 Oct 17]. Available from: http://www.paho.org/English/AD/SDE/RA/TOB_FactSheet1.pdf

6. Pinto M, Ugá MAD. The cost of tobacco-related diseases for Brazil's Unified National Health System. Cad Saude Publica 2010; 26(6):1234-1245.

7. Organización Mundial de la Salud (OMS). Convenio marco de la OMS para el control del tabaco. Geneva: OMS; 2004.

8. McKnight RH, Spiller HA. Green tobacco sickness in children and adolescents. Public Health Rep 2005; 120(6):602-605.

9. Departamento de Estudos Sócio-Econômico Rural. A cadeia produtiva do fumo. Rev Contexto $R u$ ral 2005; 5:1-68. 
10. Associação de Fumicultores Brasileiros. Fumicultura no Brasil 2009. [cited 2009 Oct 17]. Available from: http://www.afubra.com.br

11. Orr A. Green gold?: burley tobacco, smallholder agriculture, and poverty alleviation in Malawi. World Development 2000; 28(2):347-363.

12. Benson P. Good clean tobacco: Philip Morris, biocapitalism, and the social course of stigma in North Carolina. American Ethnologist 2008; 35(3):357-379.

13. Bennett EP. Manning the fields: remaking women's work in the tobacco South in the twentieth century. Journal of Peasant Studies 2008; 35(4):720-741.

14. Benson P. El Campo: faciality and structural violence in farm labor camps. Cultural Anthropology 2008; 23(4):589-629.

15. Arcury TA, Quandt SA. Health and social impacts of tobacco production. J Agromed 2006; 11(3-4):71-81.

16. Loker W M. The rise and fall of flue-cured tobacco in the Copán Valley and its environmental and social consequences. Human Ecology 2005; 33(3): 299-327.

17. Lima RG. Desenvolvimento técnico-produtivo da lavoura de tabaco na bacia hidrográfica do Rio Pardinho, RS. In: Etges VE, Ferreira MAF, organizadores. A produção do tabaco: impacto no ecossistema e na saúde humana na região de Santa Cruz do Sul, RS. Santa Cruz do Sul: EDUNISC; 2006. p. 198-224.

18. Yokoyama K. Our recent experiences with sarin poisoning cases in Japan and pesticide users with references to some selected chemicals. Neurotoxicology 2007; 28(2):364-373.

19. Ives TJ. Use of dimenhydrinate in the treatment of green tobacco sickness. Drug Intell Clin Pharm 1983; 17(7-8):548-549.

20. Arcury TA, Quandt SA, Preisser JS. Predictors of incidence and prevalence of green tobacco sickness among latino farmworkres in North Carolina, USA. J Epidemiol Community Health 2001; 55(11): 818-824.

21. Schmitt NM, Schmitt J, Kouimintzis DJ, Kirch W. Health risks in tobacco farm workers: a review of the literature. J Public Health 2007; 15(4):255-264.

22. Pugh KJ, Pienkowski D, Gorczyca JT. Musculoskeletal trauma in tobacco farming. Orthopedics 2000; 23(3):141-143.

23. Struttmann TW, Reed DK. Injuries to tobacco farmers in Kentucky. South Med J 2002; 95(8):850-856.

24. Stallones L, Beseler C. Pesticide poisoning and depressive symptoms among farm residents. Ann Epidemiol 2002; 12(6):389-394.

25. Campaign for Tobacco Free Kids. Golden leaf. Barren Harvest. The Costs of Tobacco Farming. Washington DC: National Center for Tobacco Free kids; 2001.

26. Sala G. Bolivian labor in tobacco and sugar cane production in Jujuy. Estudios Migratorios latinamericanos 2000; 45(45):337-370.

27. Vargas MA, Bonato A. Cultivo do tabaco, agricultura familiar e estratégias de diversificação no Brasil. Brasília: Ministério do Desenvolvimento Agrário; 2007.

28. McKnight RH, Kryscio RJ, Mays JR, Rodgers Junior GC. Spatial and temporal clustering of an occupational poisoning: the example of green tobacco sickness. Stat Med 1996; 15(7-9):747-757.
29. Almeida GEG. Fumo: servidão moderna e violação de direitos humanos. Curitiba: Terra de Direitos; 2005.

30. Brasil. Ministério da Saúde (MS), Instituto Nacional de Câncer (INCA), Fundação Getúlio Vargas (FGV). Cigarro brasileiro: análises e propostas para redução do consumo. Rio de Janeiro: MS, INCA, FGV; 2000.

31. Hoang VM, Kim BG, Nguyen NB, Nguyen TH. Tobacco farming in rural Vietnam: questionable economic gain but evident health risks. BMC Public Health 2009; 9:1-10.

32. Eckholm E. Cutting tobacco's toll. British-American Tobacco Company. Washington: Worldwatch Institute; 1978.

33. Weizenecker R, Deal WB. Tobacco cropper's sickness. J Fla Med Assoc 1970; 57(12):13-14.

34. Swinker M, Meredith JT. A seizure in the tobacco field: green tobacco sickness. N C Med J 2000; 61(1):390-392.

35. Arcury TA, Quandt SA, Garcia DI, Preisser Junior JS, Norton D, Rao P. A clinic-based, case-control comparison of green tobacco sickness among minority farmworkers: clues for prevention. South Medical J 2002; 95(9):1008-1011.

36. Satora L, Oszcz H, Gomólka E, Biedron W. Diplopia in Green Tobacco Sickness. J Agromedicine 2009; 14(1):66-69.

37. Bartholomay P, Iser B, Oliveira P, Santos T, Feistler A, Malta D, Sobel J, Moura L. Investigação epidemiológica da doença da folha verde do tabaco Região Sul do Brasil, dezembro de 2008. 9a Expo Epi: amostra nacional de experiências bem-sucedidas em epidemiologia, prevenção e controle de doenças. Anais / Ministério da Saúde, Secretaria de Vigilância em Saúde. Brasília: Ministério da Saúde; 2009.

38. Oliveira PPV, Sihler CB, Moura L, Malta, DC, Torres MCA, Lima SMCP , Lima ALA, Leite CE, Costa-eSilva VL, Lanzieri TM. First reported outbreak of Green tobacco sickness in Brazil. Cad Saude Publica 2010; 26(12):2263-2269.

39. Wicker GW, Guthrie FE. Worker-crop contact analysis as a means of evaluating reentry hazards. Bulletin of Environmental Contamination and Toxicology 1980; 2(1):161-167.

40. Herman ND, Hunt TW, Sheets TJ. Hand harvester exposure to maleic hydrazide ( $\mathrm{MH})$ in flue-cured tobacco. Bulletin of Environmental Contamination and Toxicology 1985; 34(4):469-475.

41. Ghosh SK, Gokani VN, Parikh JR, Doctor PB, Kashyap SK, Chatterjee BB. Protection against "green symptoms" from tobacco in Indian harvesters: a preliminary intervention study. Arch Environ Health 1987; 42(2):121-124

42. Ghosh SK, Gokani VN, Doctor PB, Parikh JR. Intervention studies against "green symptoms" among Indian tobacco harvesters. Arch Environ Health 1991; 46(5):316-317.

43. Ballard T, Ehlers J, Freund E, Auslander M, Brandt V, Halperin W. Green tobacco sickness: occupational nicotine poisoning in tobacco workers. Arch Environ Health 1995; 50(5):384-389.

44. Quandt SA, Arcury TA, Preisser JS, Norton D, Austin C. Migrant farmworkers and green tobacco sickness: new issues for an understudied disease. Am Journal Ind Med 2000; 37(3):307-315. 
45. D’Alessandro A, Benowitz NL, Muzi G, Eisner MD, Filiberto S, Fantozzi P, Montanari L, Abbritti G. Systemic nicotine exposure in tobacco harvesters. Arch Environ Health 2001; 56(3):257-263.

46. Curwin BD, Misty JH, Wayne TS, Nishioka MG, Wayne B. Nicotine exposure and decontamination on tobacco harvesters' hands. Ann Occup Hyg 2005; 49(5):407-413.

47. Arcury TA, Vallejos QM, Schulz MR, Feldman SR, Fleischer Júnior AB, Verma A, Quandt SA. Green Tobacco Sickness and Skin Integrity Among Migrant Latino Farmworkers. Am J Industrial Medicine 2008; 51(3):195-203.

48. Abraham NF, Feldman SR, Vallejos Q, Whalley LE, Brooks T, Cabral G, Earp P, Fleischr ABJr., Quandt AS, Arcury TA. Contact dermatitis in tobacco farmworkers. Contact Dermatitis 2007; 57(1):40-43.

49. Rao P, Quandt SA, Arcury TA. Hispanic farmworker interpretations of green tobacco sickness. $J \mathrm{Ru}$ ral Health 2002; 18(4):503-511.

50. Arcury TA, Quandt SA, Simmons S. Farmer health beliefs about an occupational illness that affects farmworkers: the case of green tobacco sickness. $J$ Agric Saf Health 2003; 9(1):33-45.

51. Parikh JR, Gokani VN, Doctor PB, Kulkarni PK, Shah AR, Saiyed HN. Acute and chronic health effects due to green tobacco exposure in agricultural workers. Am J Ind Med 2005; 47(6):494-499.

52. Trapé-Cardoso M, Bracker A, Grey M, Kaliszewski M, Oncken C, Ohannessian C, Barrera LV, Gould B. Shade tobacco and green tobacco sickness in Connecticut. J Environ Med 2003; 45(6):656-661.

53. Trapé-Cardoso M, Bracker A, Dauser D, Oncken C, Marrera LV, Gould B, Grey MR. Cotinine levels and green tobacco sickness among shade-tobacco workers. J Agromedicine 2005; 10(2):27-37.

54. McBride JS, Altman DG, Klein M, White W. Green tobacco sickness. Tob Control 1998; 7(3):294-298.

55. Dhar P. Measuring tobacco smoke exposure: quantifying nicotine/cotinine concentration in biological samples by colorimetry, chromatography and immunoassay methods. Journal Pharm Biomed 2004; 35(1):155-168

56. Ghosh SK, Parikh JR, Gokani NV, Kashyap SK, Chatterjee SK. Studies on occupational health problems during agricultural operation of Indian tobacco workers: a preliminary survey report. Journal Occup Med 1979; 21(1):45-47.

57. Cattaneo R, Alegretti AP, Sagebin FR, Abreu CM de, Petersen GO, Chatkin JM, Valladão TF. Validação de método para determinação de cotinina em urina por cromatografia líquida de alta eficiência. Rev Brasileira de Toxicologia 2007; 19(1):21-27.

58. Satora L, Goszcz H, Gomólka E, Biedron W. Green tobacco sickness in Poland. Pol Arch Med Wewn 2009; 119(3):184-185.

59. Onuki M, Yokoyama K, Kimura K, Sato H, Nordin RB, Naing L, Morita Y, Sakai T, Kaboyashi, Araki S. Assessment of urinary cotinine as a marker of nicotine absorption from tobacco leaves: a study on tobacco farmers in Malaysia. J Occup Health 2003; 45(3): 140-145.
60. Arcury TA, Quandt SA, Preisser JS, Norton D. The incidence of green tobacco sickness among Latino farmworkers. J Occup Environ Med 2001; 43(7):601609.

61. McKnight RH, Levine EJ, Rodgers GCJr. Detection of green tobacco sickness by a regional poison center. Vet Hum Toxicol 1994; 36(6):505-510.

62. Osim EE, Musabayane CT, Mufunda J. Lung function of Zimbabwean farm workers exposed to flue curing and stacking of tobacco leaves. S Afr Med J 1998; 88(9):1127-1131.

63. Lonsway JA, Byers ME, Dowla HLA, Panemangalore M, Antonious GF. Dermal and Respiratory Exposure of Mixers/Sprayers to Acephate, Methamidophos, and Endosulfan During Tobacco Production. Environ Contam Toxicol 1997; 59(4):179-186.

64. Ghosh SK, Parikh JR, Gokani VN. Studies on occupational health problems in agricultural tobacco workers. J Soc Occup Med 1980; 30(29):113-117.

65. Browning SR, Truszczynska H, Reed D, McKnight RH. Agricultural injuries among older Kentucky farmers: the farm family health and hazard surveillance study. Am J Ind Med 1998; 33(4):341-353.

66. Gamlin J, Diaz Romo P, Hesketh T. Exposure of young children working on Mexican tobacco plantations to organophosphorous and carbamic pesticides, indicated bycholinesterase depression. Child Care Health Dev 2007; 33(3):246-248.

67. Kimura K, Yokoyama K, Sato H, Nordin RB, Naing L, Kimura S, Okabe S, Maemo T, Kobayashi Y, Kitamura F, Araky S. Effects of pesticides on the peripheral and central nervous system in tobacco farmers in Malaysia: studies on peripheral nerve conduction, brain-evoked potentials and computerized posturography. Ind Health 2005; 43(2):285-294.

68. Salvi RM, Lara DR, Ghisolfi ES, Portela LV, Dias RD, Souza DO. Neuropsychiatric evaluation in subjects chronically exposed to organophosphate pesticides. Toxicol Sci 2003; 72(2):267-271.

69. Nicarágua. Organización Panamerica de la Salud. Efectos sanitarios y ambientales derivados del uso de plaguecidas en el cultivo del tabaco en el municipio de Jalapa. Manágua: Organización Panamericana de la Salud; 2001.

70. Alexander R, Anderson PK. Pesticide use, alternatives and workers' health in Cuba. Int J Health Serv 1984; 14(1):31-41.

71. Lobo EA, Rathke FS, Brentano DM. Ecotoxicologia aplicada: o caso dos produtores de tabaco da bacia hidrográfica do Rio Pardinho, RS, Brasil. In: Etges VE, Ferreira MAF. A produção do tabaco: impacto no ecossistema e na saúde humana na região de Santa Cruz do Sul, RS. Santa Cruz do Sul: EDUNISC; 2006. p. 41-224.

Artigo apresentado em 22/08/2011

Aprovado em 13/10/2011

Versão final apresentada em 26/10/2011 